\title{
Wstęp. Literatura Europy Środkowej w nowym tysiącleciu
}

Dzień 26 kwietnia 1984 r. okazał się kamieniem milowym w badaniach nad literaturą Europy Środkowej. Tego dnia „The New York Review of Books” opublikował esej Milana Kundery Zachód porwany albo tragedia Europy Środkowej, przetłumaczony z francuskiego oryginału z „Le Débat” (Un occident kidnappé, 1983), do dziś nieustannie cytowany i dyskutowany. W okresie przejściowym na arenie międzynarodowej ponownie ożywiły się dyskusje na temat pojęcia Europy Środkowej, które stało się przedmiotem rozważań zarówno w regionie, jak i poza nim. Zainteresowanie to pozostało żywe aż do akcesji pierwszej grupy krajów „Nowej Europy” do Unii Europejskiej w 2004 r. Obfitujące w tak wiele wydarzeń lata dziewięćdziesiąte upłynęły pod znakiem prób ustanowienia ponadnarodowego kanonu reprezentatywnych tekstów z Europy Środkowej, w skład którego wchodziłyby zarówno eseje polityczne, jak i beletrystyka lokalnych autorów, takich jak István Bibó, Jerzy Kłoczkowski, György Konrád, Josef Kroutvor lub Czesław Miłosz, przez pisarzy reprezentujących szeroko rozumianą literaturę posthabsburską, czyli Claudio Magrisa i Danilo Kiša, aż po zachodnich orędowników idei Europy Środkowej, takich jak Timothy Garton Ash. Oprócz antologii wielu wydawców inaugurowało cykle tematyczne na temat Europy Środkowej (np. projekt Arany Közép Európa (Złota Europa Środkowa) węgierskiego wydawnictwa Osiris-Századvég, serie polskiego Wydawnictwa Czarne). Pomimo narastającego nacjonalizmu istniała wciąż 


\section{Foreword. Literature of Central Europe in the New Millennium}

April 26, 1984 became a milestone for Central European Studies. Ever since The New York Review of Books had published Milan Kundera's essay, The Stolen West or The Tragedy of Central Europe, translated from the French original in Le Débat (Un occident kidnappé, 1983), it has been tirelessly quoted and debated in the field. Reflections on the term Central Europe revived on an international level and featured as a main theme in public discussions within and beyond the region amidst the transition period, an interest that remained vivid up until the integration of the first set of countries from the "New Europe" into the European Union in 2004. The long 1990 os was marked by attempts to establish a transnational canon of representative Central European texts that included both political essays and fiction by local authors like István Bibó, Jerzy Kłoczkowski, György Konrád, Josef Kroutvor or Czesław Miłosz, by writers representing the wider post-Habsburg realm like Claudio Magris and Danilo Kiš, and such Western harbingers of the Central European case as Timothy Garton Ash. Apart of anthologies a number of publishers launched thematic series on Central Europe (e.g. the Golden Central Europe project by the Hungarian Osiris-Századvég; or series by the Czarne Publishing House). Despite growing nationalism, there was a certain hope in closer cooperation not only in economic but also in cultural terms. Some examples for cultural cooperation include the Central European Initiative formed in 1989; the Visegrad Group 
nadzieja na ściślejszą współpracę pod względem nie tylko gospodarczym, ale także kulturowym. Przykładami takiego połączenia sił mogą być Inicjatywa Środkowoeuropejska utworzona w 1989 r., Grupa Wyszehradzka założona w 1991 r., Fundusz Wyszehradzki powstały w 2000 r., Międzynarodowe Centrum Kultury w Krakowie założone w 1991 r. oraz wiele innych ważnych inicjatyw o mniejszym zasięgu, takich jak np. polski Ośrodek „Pogranicze - sztuk, kultur, narodów” utworzony w 1991 r. Głównym animatorem współpracy i dialogu na temat regionu był prywatny Uniwersytet Środkowoeuropejski założony w 1991 r., w którym kształciło się wielu studentów z całej Europy Środkowo-Wschodniej.

Koncepcja Europy Środkowej była szeroko krytykowana jako narzędzie polityczne, mające służyć krajom wyszehradzkim do odcięcia się od pozostałych państw leżących „pomiędzy” Niemcami a Rosją. Istotnie, debaty w zdecydowanej większości wyczerpały się w połowie 2000 r. Badacze, którzy uznali tę koncepcję za użyteczne narzędzie analityczne, dążyli do powiązania refleksji najważniejszych postaci myśli środkowoeuropejskiej z bieżącymi zagadnieniami (np. Csaba Gy. Kiss, Jan Křen, Martin C. Putna, Ziemowit Szczerek, Andrzej Stasiuk, Simona Škrabec i Jiř́i Trávníček). Dokonywali tego, podkreślając podobieństwa czasów przeszłych i obecnych albo wyrażając, często w sposób ironiczny, dystans i sceptycyzm wobec tej koncepcji. Idea wyszehradzka zachowała jednak swój urok i, co nie jest bez znaczenia, finansowanie publiczne. Wymiana literacka pomiędzy językami Europy Środkowej jest stosunkowo bogata i żywa, reprezentują ją np.: tłumaczenia publikowane w pięciu językach i dostępne na portalu literackim Europy Środkowej (www.visegradliterature.net), wydana w pięciu językach Antologia literacka państw wyszehradzkich (Literary Anthology of Visegrad 4 Countries) oraz trzytomowa kolekcja Visegrad Drama w języku angielskim. Jednocześnie realizowana jest również szerzej zakrojona środkowoeuropejska współpraca. Najlepszym tego przykładem jest Inicjatywa Trójmorza (Three Seas Initiative), założona w 2016 r., która przecina dawną żelazną kurtynę i granice Związku Radzieckiego. Programy i inicjatywy Unii Europejskiej są formalnie otwarte dla krajów postsocjalistycznych, ale nadal dyskutowane jest to, w jakim stopniu kultura i literatura tych krajów mogłyby zostać skutecznie zaprezentowane za ich pomocą. W Europie Środkowej, podobnie jak w pozostałych formacjach, których wzajemne relacje opierają się na zasadzie niewyłączności, współpraca wydaje się nadal niezbędna, aby przeciwdziałać nierównościom gospodarczym i kulturowym w Unii Europejskiej.

W tym numerze wydawanego dwa razy w roku czasopisma „Porównania” autorzy zajmujący się literaturami czeską, polską, słowacką i węgierską dokonują 
founded in 1991 and Visegrad Fund set up in 200o; Krakow Międzynarodowe Centrum Kultury (International Cultural Centre) founded in 1991; and many other smaller important initiatives, such as the Polish Ośrodek "Pogranicze sztuk, kultur, narodów" ("The Borderland-of arts, cultures, nations" centre) formed in 1991. A major animator of cooperation and discussions about the region was the private Central European University established in 1991, that brought together many students from all over Eastern Europe.

The concept of Central Europe has been widely criticized as a political tool of the Visegrad countries to dissociate themselves from other lands "in between" Germany and Russia. Indeed, debates largely exhausted by the mid-20oos. Those scholars from the Humanities who kept an interest in the concept as an analytical tool aspired to relate reflections of former icons of Central European thought to current matters (e.g. Csaba Gy. Kiss, Jan Křen, Martin C. Putna, Ziemowit Szczerek, Andrzej Stasiuk, Simona Škrabec and Jiří Trávníček), either by emphasizing the similarities and parallels of past and contemporary situations or by expressing, often ironically, their distance and scepticism towards the very concept they employ. The Visegrad idea, however, still kept some of its appeal and, significantly, public funding. Literary exchanges between Central European languages have been relatively varied and extensive, f.e.: translations published in five languages are accessible for instance on the Central European literary portal (www.visegradliterature.net); a Literary Anthology of Visegrad 4 Countries was published in five languages, and a three volume collection represents the "Visegrad Drama" to an English audience. At the same time, such Central European cooperations continue within wider and more inclusive frames, for instance as part of the Three Seas Initiative, founded in 2016, that cuts across the former Iron Curtain and the former borders of the Soviet Union. The programs and initiatives of the European Union are formally open to post-socialist countries, but it has been debated at what extent the culture and literatures of these countries could effectively represent themselves via such programs and platforms. In any case, Central European collaboration, along with other cooperative formations on a non-exclusivist basis, seems to remain necessary to counter economic and cultural inequality within the EU.

This issue of the 6-monthly journal Porównania (Comparisons) brings together a collective of authors working on Czech, Hungarian, Polish and Slovak literatures to initiate an assessment of the present status of literature in Central Europe in the 21st century-which is, in many sense, a "post-Central European" epoch.

One of the major concerns of the thematic issue is collective memory as represented or reflected in contemporary literature, especially with regard 
przeglądu ich stanu w XxI w., który pod wieloma względami uznać można za epokę „postśrodkowoeuropejską”.

Jedną z głównych kwestii poruszanych w niniejszym tomie jest pamięć zbiorowa. Jej obecność w literaturze współczesnej daje się zauważyć szczególnie w odniesieniu do najważniejszych wydarzeń xx w., które ukształtowały sposób, w jaki państwa Europy Środkowej postrzegają swoją tożsamość i historię. Bogusław Bakuła w studium zatytułowanym 1956, 1968, 1981 - oblicza środkowoeuropejskiej pamięci. Uwagi w perspektywie postkolonialnej (1956, 1968, 1981: The Faces of Central-European Memory: A Postcolonial Perspective) wprowadza trójdzielny system kategorii: pamięci wspólnej, pamięci odrębnej i nie-pamięci. Służy on przede wszystkim rozróżnieniu praktyk pamięciowych w literaturze Europy Środkowej. Autor dochodzi do wniosku, że efektem kondycji postkolonialnej tego obszaru jest dominacja nie-pamięci (znaczącej luki w podejmowaniu szczególnie trudnych tematów historycznych) i pamięci odrębnej (która wzmacnia istniejące już narracje narodowe). Niełatwe zadanie podjęcia dyskusji na temat wspólnej pamięci wciąż pozostaje wyzwaniem. Z kolei Tamás Kisantal w artykule Poza pobojowiskami pamięci. Historyczne traumy i literatura wegierska (Beyond the Battlefields of Memory: Historical Traumas and Hungarian Literature) analizuje współczesną literaturę węgierską przez pryzmat zupełnie innego zestawu pojęć, zapożyczonych od Michaela Rothberga. Mimo to wnioski obu badaczy są podobne. Kisantal twierdzi, że pamięć rywalizacyjna w sferze publicznej przyczyniła się do względnego zaniedbania we współczesnej literaturze opisu traumatycznych wydarzeń. Ma jednak nadzieję, powołując się na kilka obiecujących przykładów, że pamięć wielokierunkowa może pomóc w zmianie sposobu myślenia, zwłaszcza dzięki wyłaniającemu się nowemu nurtowi literackiemu, jakim jest powieść historyczna (historical fiction).

Podobny nowy trend opisuje Alena Šidáková Fialová w tekście Powrót do przeszłości. Niemcy jako trauma historyczna we współczesnej literaturze czeskiej (Returning to the Past: The Germans as a Historical Trauma in Contemporary Czech Prose). Na podstawie analizy najnowszej literatury czeskiej przedstawia skomplikowaną relację pomiędzy Czechami a Niemcami. Przyglądając się obecnej we współczesnej beletrystyce refleksji dotyczącej traumy historycznej związanej z kwestią niemiecką, Autorka zauważa, że posługiwanie się gatunkiem sagi rodzinnej oraz celowe zacieranie granic pomiędzy fikcją i reportażem często służą podważaniu ram zastanych konwencji literackich. Vladimír Barborík w artykule Pamięć i historia. Ujęcia przeszłości w słowackiej prozie po 2000 r. (Memory and History: A Comparison of the Past in Slovak Prose of the Post-20oo Period) odnotowuje ponowne zainteresowanie historią 
outstanding events of the twentieth century that have shaped national self-perceptions in Central Europe. In his study entitled 1956, 1968, 1981: The Faces of Central-European Memory: A Postcolonial Perspective Bogusław Bakuła introduces the tripartite category system of shared memory, separate memory and non-memory in order to differentiate between various memory pracices articulated through literature written in Central Europe. He concludes that as a result of the postcolonial condition non-memory (that is a striking absence in addressing certain historical themes) and separate memory (that reinforces existing national narratives) prevail. The difficult task of negotiating shared memories remains a so far unachieved ideal. Tamás Kisantal in his Beyond the Battlefields of Memory: Historical Traumas and Hungarian Literature approaches contemporary Hungarian literature with a different set of concepts borrowed from Michael Rothberg, but with very similar results. Kisantal asserts that competitive memory in the public sphere greatly contributed to the relative negligence of traumatic events in contemporary literature. Drawing on a few promising examples he nevertheless hopes that multidirectional memory has a chance to change directions precisely through an emerging new trend of historical fiction.

A similar new trend is described by Alena Šidáková Fialová in her paper Returning to the Past: The Germans as a Historical Trauma in Contemporary Czech Prose in which she surveys the struggle with the complicated relationship of Czechs and Germans as represented in recent Czech literature. Tracing German-related historical trauma in contemporary fiction she points at the importance of family saga and the playful blur of fiction and documentative prose in challenging previous modes of writing. Vladimír Barborík in Memory and History: A Comparison of the Past in Slovak Prose of the Post-20oo Period also senses a renewed interest in history in the most recent Slovak prose, and just as in the Czech and Hungarian cases the documentative turn seems to taking shape-an impression that is reinforced by the analysis of new type of genre in Aleš Merenus's and Marek Lollok's The Image of the Czech Past in the Contemporary Docudrama. In Barborík's analysis, he focuses on how autobiographical writing affected the style of fictional biographies, a new trend in Slovakia that he traces back to Silvester Lavrík's prose. Writing on the 1989 political turn in Hungarian literature in Romania, Imre József Balázs (Hungarian Stories of the Regime Change: Voices and Perspectives) attributes a similar paradigm-changing role to Ádám Bodor, a native of Transylvania who repatriated to Hungary in the 1980 . In contrast of literary critics' often voiced expectation that the regime change should be depicted in some kind of grand narrative and in a broad panorama, Bodor's own indirect tackling of the topic challanged the possibility of a master 
najnowszą w prozie słowackiej. W swojej analizie Barborík koncentruje się na tym, jak pisanie autobiograficzne wpłynęło na styl fikcyjnych biografii, nowego trendu na Słowacji, który nawiązuje do prozy Silvestra Lavríka. Podobnie jak w przypadku Czech i Węgier okazuje się, że dominuje tutaj i nabiera kształtu zwrot dokumentacyjny. Wrażenie to potwierdza analiza nowoczesnej odmiany gatunkowej autorstwa Aleša Merenusa i Marka Lolloka w artykule Obraz czeskiej przeszłości we współczesnych sztukach teatralnych typu „dokudrama” (The Image of the Czech Past in the Contemporary Docudrama). Pisząc o zwrotach politycznych z 1989 r. w literaturze węgierskiej z Rumunii, Imre József Balázs (Wegierskie historie o zmianie ustroju. Głosy i perspektywy - Hungarian Stories of the Regime Change: Voices and Perspectives) przypisuje podobną, zmieniająca paradygmat rolę Ádámowi Bodorowi, rodakowi z Transylwanii, który w latach osiemdziesiątych xx w. powrócił na Węgry. Krytycy literaccy często wyrażali opinię, że zmianę ustrojową należy przedstawić za pomocą wielkiej narracji czy szerokiej panoramy, a pośrednie zajęcie się tym tematem przez Bodora podważyło możliwość zaistnienia takiej narracji. W jego ślady poszła również grupa młodszych autorów. Otwarci na wiele interpretacji skupiali się na drobnych, prywatnych doświadczeniach, a nie na ważnych wydarzeniach historycznych.

Podkreślając znaczenie literatury mniejszościowej, z istoty przyjmującej bardziej złożony punkt widzenia niż kultura narodowa, Balázs wskazuje na znaczenie terytorialności w beletrystyce pamięciowej. Ten temat rozwija Przemysław Czapliński w pracy Literatura i geografia (Literature and Geography). Przygląda się procesowi zmiany wyobraźni geograficznej w literaturze polskiej w latach 1986-2016. Śledzi stopniową samoizolację, która wynika z coraz większego nacisku na sprawy lokalne i kurczenie się przestrzeni literackiej we współczesnej beletrystyce. Znaczenie opracowywania problematyki prozy wielokulturowych regionów literackich podkreśla Lukáš Pěchula w artykule zatytułowanym Konstruowanie polskiego heteroimage'u w międzywojennych powieściach z regionu Ostrawy. Czesko-niemieckie studium imagologiczne (Das Bild der Polen als Heterokonstruktion in Zwischenkriegsromanen der Region Ostravsko: Tschechisch-deutsche imagologische Untersuchung). Bada on, w jaki sposób obrazy polskiej heterogeniczności kulturowej zostały skonstruowane w powieściach międzywojennych autorstwa czeskich i niemieckich pisarzy z obszaru Moraw i Śląska, którego centrum, a jednocześnie głównym celem polskiej emigracji była wówczas Ostrawa. Ze względu na różnorodność kulturową wynikającą z zamieszkiwania na tym obszarze Polaków, Czechów, Niemców i Żydów oraz dominującą obecność elementu czeskiego po II wojnie światowej stanowi ona przykład dobrze znanej drogi homogenizacji kulturowej w Europie Środkowo -Wschodniej. Radek Malý z kolei osadza czeskich poetów w szerszych, ale nie 
narrative. In his footsteps, a cohort of younger authors employ playful narratives from below open to multiple interpretations and focus on small-scale private experiences rather than major events.

By stressing the importance of minority literatures in the region that tend to have a broader view than a single culture by definition, Balázs pointed at the significance of territoriality in memory fiction. This is what concerns Przemysław Czapliński in Literature and Geography that follows the process of how geographical imagination changed in Polish literature between 1986 and 2016. Czapliński identifies a gradual self-isolation by an increased focus on the domestic and a shrinking of literary space in fiction. The importance of mapping the fiction of multicultural literary regions is stressed by Lukás Pěchula in his study Constructing Polish Heteroimage in the Interwar Novels of the Wider Ostrava Region (Das Bild der Polen als Heterokonstruktion in Zwischenkriegsromanen der Region Ostravsko: Tschechisch-deutsche imagologische Untersuchung). He explores how Polish hetero images were constructed in interwar novels by Czech and German writers in Moravia-Silesia with Ostrava in its center that was a primary target of Polish immigration in the epoch and notable of its cultural heterogeneity with Poles, Czechs, Germans and Jews living in the area-just to become predominantly Czech after the Second World War, which is an all too well-know East Central European trajectory of cultural homogenization. Radek Malýs paper embeds Czech poets in a wider, but not less multicultural framework. The Figure of Ophelia in Expressionist Poetry: German and Czech Comparison employs the classic toolkit of the comparatist to show the intimate affinity of European literatures. Malý traces a single figure originated in English literature that was rewritten by German Expressionists and Czech modernists: Ophelia, and revisits the multiple uses of this figure in the light of the Ophelia complex as defined by Gaston Bachelard.

Czapliński wonders in his mentioned paper on Literature and Geography whether new narratives will be developed that interconnect Poland with its neighbouring countries and thus situate Poland better on a European cultural map remains a question for the future. The process of how a Central European literature can affirm its place in the new world literary scene is also a preoccupation of Zsuzsanna Varga in The Networks of Consecration: The Journey of Magda Szabó and László Krasznahorkai’s International Reputation. Focusing on the few outstanding Hungarian literary success-stories in the past decades, she highlights the importance of human agency. Challenging views that overemphasize the significance of international literary prizes and positive reviews in prestigious periodicals, she stresses the invisible personal investment of a network of translators and cultural mediators fluent in multiple languages 
mniej wielokulturowych ramach - w tekście Figura Ofelii w poezji ekspresjonistycznej. Niemiecko-czeskie porównanie (The Figure of Ophelia in Expressionist Poetry: German and Czech Comparison) wykorzystuje klasyczny zestaw narzędzi komparatystycznych, aby ukazać bliskie powinowactwa literatur europejskich. Malý, przyglądając się postaci pochodzącej z literatury angielskiej i przepisanej przez niemieckich ekspresjonistów oraz czeskich modernistów, odwołuje się do wielu zastosowań tej postaci w świetle kompleksu Ofelii zdefiniowanego przez Gastona Bachelarda.

Czapliński we wspomnianym już artykule Literatura i geografia zastanawia się nad tym, czy powstaną nowe narracje, które połączą Polskę z krajami sąsiadującymi i tym samym pozwolą jej na zajęcie odpowiedniego miejsca na europejskiej mapie kulturowej. Proces, w którym literatura Europy Środkowej stara się potwierdzić swoją obecność na nowej światowej scenie literackiej, jest również przedmiotem zainteresowania Zsuzsanny Vargi w studium Sieci święcenia - droga Magdy Szabó i László Krasznahorkaiego do międzynarodowej popularności (The Networks of Consecration: The Journey of Magda Szabó and László Krasznahorkai’s International Reputation). Skupiając się na kilku wybitnych sukcesach literatury węgierskiej ostatnich dziesięcioleci, podkreśla ona znaczenie konkretnych działań części całego procesu. Podaje w wątpliwość przywiązywanie zbyt dużej wagi do międzynarodowych nagród literackich i pozytywnych recenzji w prestiżowych periodykach, jednocześnie zwracając uwagę na osobiste zaangażowanie sieci tłumaczy i mediatorów kultury biegle posługujących się wieloma językami, co jest równie istotne w promowaniu autorów nie tylko w Europie, ale i na całym świecie.

Tematem badań Ágnes Györke w artykule Współczesne węgierskie pisarstwo kobiece i kosmopolityzm (Contemporary Hungarian Women's Writing and Cosmopolitanism) jest odtwarzanie przestrzeni i przekraczanie granic, choć w mniej praktycznym i literackim sensie. Skupiając się na trzech przedstawicielkach gender-conscious („świadomości płci”), istotnego trendu w literaturze węgierskiej po 2000 r., podważających patriarchalne normy pisania literatury, Györke pokazuje, w jaki sposób autorki te „zgłębiają idę̨ przekonującą, że kobiety muszą wykroczyć poza przypisaną im przestrzeń" i wejść w stałą świadomość swojego ciała i interakcję z przestrzenią miejską. Przypisuje ona omawiane utwory kosmopolitycznemu feminizmowi, wskazując na to, jak duże może mieć on znaczenie w przezwyciężeniu ściśle tradycyjnego spojrzenia na literaturę w całym regionie. Testowanie granic tradycji narodowej jest jednym $\mathrm{z}$ tematów pojawiających się również w pracy Kláry Kudlovej. W przeciwieństwie do większości autorów z tego zbioru Kudlová skupia się na interpretacji utworów jednego autora, Jáchyma Topola, dążąc do pokazania w jego dorobku 
as equally crucial factors in bringing authors to the fore in a European and global cultural space.

Recreating space and crossing borders: this is the topic of Ágnes Györke's study, Contemporary Hungarian Women's Writing and Cosmopolitanism, though in a less practical and more literary sense. Focusing on three representatives of a significant gender-conscious trend of post-200o Hungarian literature that challanged the partiarchal norms on how to write literature, Györke shows the ways these authors "explore the idea that women need to go beyond their designated space" in a constant awareness of their body and interaction with mundane environments of the city. She positions this kind of fiction in the realm of cosmopolitan feminism pointing out its relevance to overcoming the rigidly traditonalist literary field in the entire region. Testing the limits of the national tradition is one of the themes that appear in Klára Kudlovás paper. In contrast to most articles in this collection, Kudlová provides an interpretation of a single author, Jáchym Topol, but through his writing she provides an example of how to reframe a national literary tradition in a broader Central European system of references. On Fields of Bones, Headsmen and Madonnas. The Symbols and Figures of Central Europe in the Past 25 Years of Jáchym Topol's Writing shows how the three tropes in the title of her article become symbols of a common Central European space in the Czech writer's drama and fiction.

The papers addressing contemporary poetry also raise the question of redefining relations to traditions. In her essay Temporalities-Technologies-Transgressions: On Contemporary Slovak Poetry, Ivana Hostová drawing on an approach taken from Peter Osborne (according to which, only post-conceptual poetry makes sense at present) she concludes that the trans- and inter-cultural spaces being created in Slovak poetry of the past three decades give some hope that the intensifying globalising tendencies of the present will at least partially be slowed down. Markéta Kittlová in Changing the World Through Poetry: Confessions, Poems and Banners of Adam Borzič features Adam Borzič as a contemporary poet reconsidering the social role of poetry as envisioned by T.S. Eliot and how it might reshape reality.

One of the major changes in the literary field since 2000 has been the emergence of the Internet and the social media. Karel Piorecký and Vojtěch Malínek (Czech Literary Culture in the Post-Digital Era) argues based on Czech examples that the new media changed the book market and assigned a renewed agency on the reader. Based on the analysis of the Polish online literary scene Elżbieta Winiecka goes on to claim that literary criticism and literature are developing into hybrid forms between the art of writing and audio-visual media. In Literary Internet: Online Criticism and Literary Communication she nevertheless alerts for the dangers of far-fetched interpretations. 
przykładu przeformułowania narodowej tradycji literackiej w szerszym środkowoeuropejskim systemie odniesień. W tekście Kości, kaci i madonny. Symbole i figury Europy Środkowej w twórczości Jáchyma Topola ostatnich 25 lat (On Fields of Bones, Headsmen and Madonnas. The Symbols and Figures of Central Europe in the Past 25 Years of Jáchym Topol's Writing) udowadnia, jak wymienione tropy stają się symbolami wspólnej przestrzeni Europy w dramacie i beletrystyce czeskiego pisarza.

Artykuły dotyczące współczesnej poezji poruszają także kwestię przedefiniowania podejścia do tradycji. W eseju Temporalności - technologie - transgresje. O współczesnej poezji słowackiej (Temporalities - Technologies - Transgressions: On Contemporary Slovak Poetry) Ivana Hostová, czerpiąc z analiz Petera Osborne’a (zgodnie z którymi sens ma obecnie tylko poezja postkonceptualna), dochodzi do wniosku, że trans- i interkulturowe przestrzenie tworzone w słowackiej poezji ostatnich trzech dekad dają nadzieję na przynajmniej częściowe spowolnienie nasilających się tendencji globalizacyjnych. Markéta Kittlová $\mathrm{w}$ tekście Zmienić świat przez poezję. Wyznania, wiersze i banery Adama Borziča (Changing the World Through Poetry: Confessions, Poems and Banners of Adam Borzič) przedstawia czeskiego twórcę jako współczesnego poetę, zastanawiającego się nad społeczną rolą poezji, o której pisał T.S. Eliot, i nad tym, w jaki sposób może ona przekształcić rzeczywistość.

Jedną z głównych zmian, jakie dotknęły literaturę po 2000 r., było pojawienie się Internetu i mediów społecznościowych. Karel Piorecký i Vojtěch Malínek (Czeska kultura literacka erze (post)cyfrowej - Czech Literary Culture in the Post-Digital Era) dowodzą na przykładach z kultury czeskiej i słowackiej, że nowe media zmieniły rynek książki i przywróciły czytelnikowi sprawczość. Na podstawie analizy polskiej internetowej sceny literackiej Elżbieta Winiecka twierdzi, że krytyka literacka i literatura stają się hybrydowymi formami pomiędzy sztuką pisania a mediami audiowizualnymi. W studium Literacki Internet. Uwagi o krytyce i komunikacji literackiej w Sieci (Literary Internet: Online Criticism and Literary Communication) ostrzega jednak przed niebezpieczeństwami, jakie niosą tak daleko idące interpretacje.

Kategoria obywatelstwa ma bezsprzecznie długi rodowód w Europie Środkowej. Społeczeństwo obywatelskie musi jednak nieustannie negocjować swój modus vivendi między oczekiwaniami Zachodu (czasem kierującymi się podwójnymi standardami i często opartymi na pobieżnie odczytanych informacjach), tendencjami autorytarnymi w lokalnej polityce i globalnymi wyzwaniami, takimi jak kryzys uchodźczy w 2015 r. i obecna pandemia. Przykładowymi wskaźnikami statusu społeczeństwa obywatelskiego są: jego związek z własną przeszłością i wyobrażenia na temat przyszłości. Przyjrzenie się głównym 
Civility has, arguably, considerable traditions in Central Europe, civil society, however, needs to constantly negotiate its modus vivendi between Western expectations (sometimes driven by double-standards and often based on half-digested information), authoritarian tendencies in local politics, and global challenges such as the 2015 refugee crisis and the current Coronavirus pandemic. One of the possible indicators of a civil society's status is its relation to its own past and its imagination of its future. A look at major trends and tendencies in literature might not only reveal how approaches, themes and poetics change, but also help us to understand our societies' efforts to tackle an increasingly diversified cultural landscape.

\author{
Alena Šidáková Fialová \\ (guest editor of papers on Czech literature) \\ Tamás Scheibner \\ (guest editor of papers on Hungarian literature) \\ Lenka Németh Vitová \\ (editor of papers on Polish literature)
}

The editorial board would like to thank Radoslav Passia, PhD for his assistance in editing the articles dealing with Slovak literature. 
trendom i tendencjom w literaturze może nie tylko ujawnić, w jaki sposób zmieniają się podejścia, wątki i poetyki, ale także pomóc zrozumieć wysiłki podejmowane przez społeczeństwa, by stawić czoła coraz bardziej zróżnicowanemu krajobrazowi kulturowemu.

\author{
Alena Šidáková Fialová \\ (redaktor gościnny artykułów na temat literatury czeskiej) \\ Tamás Scheibner \\ (redaktor gościnny artykułów na temat literatury wegierskiej) \\ Lenka Németh Vítová \\ (redaktor artykułów na temat literatury polskiej)
}

Redakcja pragnie podziękować dr. Radoslavowi Passii za pomoc podczas redakcji artykułów dotyczących literatury słowackiej. 